\title{
As imagens de cidade na poesia de João Cabral de Melo Neto
}

Mércia Fernandes Universidade Federal de Minas Gerais $(\ldots)$
A cidade diária,
como um jornal que todos liam,
ganhava um pulmão de cimento e vidro.
Joào Cabral de Melo Neto

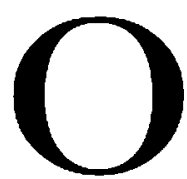

poeta que escreve os seus poemas com a disciplina matemática de um engenheiro é itinerante e, ao longo do percurso, deixa inúmeras edificações. Por vezes, cidades inteiras construídas com o árduo trabalho das palavras. Conhecer suas cidades implica uma disposição para compreender os recursos estruturadores, subjacentes a seu fazer poético. Com efeito, as cidades presentes na poesia cabralina possuem os mesmos traços caracterizadores de sua poética. Inversamente, a poesia toma "lições" das cidades com as quais Cabral estabelece contato durante o exercício da profissão de diplomata.

Propõe-se um tour pelas cidades de sua obra, a fim de se explicitar a relação existente entre as cidades e a poesia cabralinas. Uma visita assim pressupõe que se determine de antemão o itinerário. Há duas cidades centrais para as quais todas as outras convergem nesta poesia: Recife e Sevilha. Nelas, portanto, deve-se permanecer por mais tempo. Mas o caminho também passa por outras cidades que permitem uma volta completa pelo universo poético de Cabral. Do Brasil à Espanha, de paises latino-americanos a toda a Europa, passando pela África, tem-se a possibilidade de uma viagem esclarecedora de inúmeras questōes. É rumo a estas outras cidades que seguiremos viagem por ora. A capital pernambucana e a capital andaluza demandam maior tempo e espaço para serem observadas e analisadas, portanto, não nos deteremos nelas neste momento. 


\section{Poesia e cidade cabralinas: 0 impasse entre tradição e modernidade}

Comungando com as tendências racionalizadoras do pensamento urbanístico moderno e incorporando-as à sua própria estrutura, a poesia de João Cabral de Melo Neto constrói a representação das cidades que aborda identificando nelas estes mesmos quesitos. Por conseguinte, as cidades cabralinas também falam de sua poesia. Já se tornou lugar-comum, na fortuna crítica, o apontamento dos traços metalingüisticos da produção literária de João Cabral de Melo Neto; de novo, as imagens de cidacles vêm evidenciá-los. Todas elas possuem algum aspecto característico que está nos versos. João Cabral olha para as cidades com a perspectiva de poeta construtor e reconhece nelas os materiais de trabalho que deseja para o fazer poético. Elas ensinam-lhe, então, como deve ser a construção. $O$ movimento é permutativo: as cidades literárias são edificadas a partir dos mesmos pressupostos que regem a realização dos poemas; reciprocamente, a poesia aprende das paisagens citadinas características como a exatidão e contenção, nas quais deve se espelhar.

Iniciemos o tour pelas cidades cabralinas. Na viagem podemos avistar os elementos capazes de desvendar estas proposições. O primeiro ponto de parada é Brasília:

Aqui, as horizontais descampinadas

farào o que os alpendres remansos, alargando espaçoso o tempo do homem

de tempo atravancado e sem quandos.'

A imagem de Brasília possui em si o contraste entre a construção plana e retilínea própria da ciclade - horizontais descampinadas - e a retração dos alpendres. No entanto, a oposição é apenas aparente, pois os alpendres representam a vida "sem ânsia", que dissolve o "agarrotamento"z do homem. Alpendres e horizontalização são, então, equivalentes e remetem à idéia de ampliação. Neste sentido, o confronto se efetiva entre outros dois elementos, tempo e espaço. A categoria temporal remete à idéia de movimento, pois pressupõe uma seqüência com ponto inicial,

\footnotetext{
' MELO NETO, 1999. p. 348.

2 MELO NETO, 1999. p. 342.
} 
outros intermediários até a consumação do ponto que finaliza a ordenação. Ao contrário, toda instância espacial corresponde mais à ordem do estático que do movimento. Não obstante, é o tempo que se apresenta "atravancado" e sofre a ampliação dos "alpendres espaçosos, de largo". 3

A predominância espacial é visivel também na construção poética de João Cabral de Melo Neto. O estudo de Helton Gonçalves de Souza enfatiza, a partir da aproximação com a "matemática plástica" do pintor Mondrian, a materialidade gráfica, muito embora ainda ligada à tradição do verso lingüístico, da poesia de Joño Cabral:

...na criaçào poética de JCMN, o jogo de relações dos textos transpỏe o aspecto tão somente temático (ou tópico) e se estabelece também no aspecto formal ou, mais propriamente ainda, visual do poema, valorizando desse modo esse elemento que a fenomenologia do texto literário denomina estrato ótico. E o resultado dessas relações sempre dá a ver, como um traço sistemático da obra cabralina, o artesanato de formas assimétricas que equilibram-se na percepçio final do seu arranjo. ${ }^{4}$

O "dar a ver" desta poesia, que molda um artesanato de formas assimétricas, para usar termos do crítico, configura uma formulação estética cuja disposição espacial se torna elemento indispensável. Do leitor, Cabral exige atenção para os sinais relacionais entre as estrofes de cada poema, o número de versos nelas contidos, as medidas estróficas propriamente ditas. Estes requisitos demandam a ativiclade do olhar; correspondem, muito mais, portanto, à dimensão espacial que à temporal. O resultado semântico desta espacialidade poética é um sentido de equilibrio e racionalidade.

Detendo-nos no poema "À Brasília de Oscar Niemeyer", poderemos observar outras facetas da ciclade:

Eis casas-grandes de engenho, horizontais, escancaradas, onde se existe em extensão e a alma todoaberta se espraia.s

${ }^{3}$ MELO NETO, 1999. p. 348.

${ }^{4}$ SOUZA, 1999. p. 63.

s MELO NETO, 1999. p. 399. 
A cidade da poesia se comunica com a imagem já instituída da cidade empírica. Assim, é elaborado o espaço imaginário - estabelecido a partir de escolhas pessoais e registrado em versos - que distingue 0 limiar entre a perspectiva já instituida socialmente e a individual. Desta maneira, o espaço aberto de Brasília, ocasionado pela dimensão horizontal que a caracteriza, é apresentado no poema como "escancarado", e o habitar possivel o que se realiza em "extensão". Extensão, "escancaramento", o "espraiar da alma todoaberta" pertencem ao mesmo campo semântico sugerido pela expressão "horizontalidade", e refletem a concepção modernizadora que orientou a construção da capital brasileira, a qual é endossada pela poética cabralina.

Mostrando o vínculo entre modernidade e cultura urbana, bem como a associação modernidade-ruptura com a tradição, Luis Alberto Brandão Santos, no artigo "A cidade arcaica", desvela os "pontos comuns entre o pensamento modernizador que fundamentou a concepção e a construção de Brasília e as opções estéticas que alicerçam a obra poética de João Cabral de Melo Neto". ${ }^{6}$ O ímpeto ordenador, explícito na importância dada ao planejamento, na edificação da capital brasileira radicaliza, segundo Brandão Santos, o projeto moderno de romper com a tradição e fundar uma nova ordem a partir do vazio. E, de fato, esta a impressão transmitida pela horizontalidade de Brasília, referida pelo poeta, ao olhar que a percorre: a de uma cidade erguida a partir de uma ausência anterior.

Em seguida, o artigo mostra como a poética cabralina, ao eleger a "concretude do "fora" e propor o "esvaziamento" do "dentro" (estas expressões indicam uma recusa à subjetividade proposta pela tradição romântica), partilha do ideal modernista, realizado em Brasilia, de "edificar do nada", pois "o gesto do poeta é o gesto daqueles que "têm um vazio a preencher"."

Mas o aval da poesia de João Cabral de Melo Neto ao projeto moderno não é acrítico. No mesmo poema, fica claro o apontamento do

' SANTOS, 1999, v. 6, p. 86.

7 SANTOS, 1999, v. 6, p. 87.

${ }^{8}$ PORTINARI, citado por SANTOS, 1999, v.6, p. 87.

9 MELO NETO, citado por SANTOS, 1999, v.6, p. 87. 
caráter arcaizante do intuito modernizador, ao se comparar os palácios com as casas-grandes de engenho: ambos possuem estratégias semelhantes de dominação. A similaridade fica mais evidente no poema "Uma mineira em Brasilia":

No cimento de Brasília se resguardam maneiras de casa antiga de fazenda, de copiar, de casa grande de engenho. ${ }^{10}$

Cimento duro, símbolo da modernização urbana, se enlaça ao carnal da alvenaria das casas de fazenda. Por ser um dos que Benedito Nunes chamou de poemas permutacionais, referindo-se ao procedimento neles perceptivel de produzir novos poemas pela reelaboração de outros já existentes (Helton Gonçalves, como já foi mencionado neste trabalho, se detém sobre esse prisma da poesia cabralina ao aproximá-la da obra de Juan Miró, e o denomina "autotextualidade"), este poema apresenta considerações comuns a um outro poema, "Mesma mineira em Brasília:"

No cimento duro, de aço e de cimento,

Brasília enxertou-se, e guarda vivo, esse poroso quase carnal de alvenaria da casa de fazenda do Brasil antigo."

Outra cidade, Olinda, também funde em sua constituição elementos característicos das construções antigas junto a uma perspectiva que avaliza os métodos e ideais do urbanismo moderno. É assim, pois, que se justapõem geometria e alvenaria, perfil duro e fio gasto, formato de cubos e ancas redondas, bem como se pode identificar um tijolo que participa de uma natureza oposta à sua, ser farelento:

Olinda não usa cimento.

Usa um tijolo farelento.

Mesmo com tanta geometria

Olinda é já de alvenaria.

Vista de longe (tantos cubos)

ela anuncia um perfil duro.

Porém de perto seus sobrados

revelam esse fio gasto

\footnotetext{
${ }^{10}$ MELO NETO, 1999. p. 343.

" MELO NETO, 1999. p. 347.
} 
da madeira muito roçada, das paredes muito caiadas, de ancas redondas, usuais nas casas velhas e animais.

Porque Olinda, uma Olinda baixa, se mistura com o mar na praia: que é por onde se vào infiltrar em seu corpo os cupins do mar. ${ }^{12}$

Com efeito, considerações afirmativas em torno da geometrização e regularização da cidade são nódulos centrais das conceituaçōes modernas, tais como as de Le Corbusier, de quem Joño Cabral de Melo Neto afirma ter apreendido a obsessão pela construção em poesia. ${ }^{13}$

No livro Urbanismo, Le Corbusier critica a ineficiência dos modelos citadinos de então e aponta-lhe a causa: a desregularidade de seus traçados, que não atendem mais as necessidades dos novos tempos. Em virtude deste estado, as cidades estariam próximas de uma condição de barbarismo, à qual corresponde um estado de malestar. Em contrapartida, um sentimento de bem-estar se apresentaria assim que a ordem fosse restabelecida:

Quando a linha for contínua, regular, quando as formas tiverem um invólucro sem nenhuma ruptura, condicionadas por uma regra clara, nossos sentidos serào afagados; nosso espírito ficari enlevado, liberto, fora do caos, inundado de luz; pensará "domínio", se elevará e sorriremos. ${ }^{14}$

Posicionamento semelhante pode ser vislumbrado, no poema, pela distinçào das duas possiveis focalizações sobre Olinda: a de longe, que aparenta regularidade geométrica (tantos cubos), e a de perto, na qual se revelam seus traços disformes. A desproporção percebida com a proximidade do olhar encontra uma justificativa na última estrofe; ela é oriunda de uma outra divisão: a divisão social.

O poema "Olinda revisited" mostra a cidade sob a perspectiva daquele que, não a conhecendo, por ela transita. Se, a princípio, observando-a por fora,

12 MELO NETO, 1999. p. 235-236.

${ }^{13}$ Confira entrevista em SECCHIN, 1999.

${ }^{14}$ LE CORBUSIER, 2000. p. 56. 
O estranho-de-mais-longe

sente a morna franqueza

que expressa sua fachada

(mesmo quando se fecha) ${ }^{15}$

quando dentro dela se encontra, o visitante sente que

Poucas cidades ainda

(...)

podem dar a quem passa

a intimidade aquela

de quem vive uma casa

como outra matriz terna ${ }^{16}$

Olinda é comparada a uma casa por causa da qualidade de acolhimento, que permite o estabelecimento de um contato íntimo. Impossível, então, não fazer a associação deste poema com um anterior, que não se refere a nenhuma cidade propriamente, mas que ajuda a entender a lógica da correlação entre casa e intimidade. Trata-se do poema "A mulher e a casa". No poema de Quaderna, mulher e casa são cotejadas em seus predicados sedutores. A voz lírica chega à conclusão que ambas não podem ser contempladas apenas pelo que apresentam na fachada presunção similar foi feita a respeito da cidade pernambucana - , pois a impressão recolhida não fala daquilo que de fato são. Faz-se necessário perscrutá-las por dentro, onde:

estâncias aconchegadas, paredes bem revestidas

ou recessos bons de cava,

exercem sobre esse homem

efeito igual ao que causas:

a vontacle de corrê-la

por dentro, de visitá-la."

É, portanto, pelos atributos vinculados à idéia de abrigo e comodidade que casa, mulher e cidade se atam. Há ainda um matiz erótico

\footnotetext{
15 MELO NETO, 1999. p. 431.

16 MELO NETO, 1999.p. 431.

17 MELO NETO, 1999. p. 242.
} 
nos dois poemas a sugerir a efetivação do aconchego desejado pela penetraçâo íntima. Assim, os últimos versos do poema sobre Olinda dispõem ludicamente o homônimo perfeito casa, de modo a sugerir uma relação matrimonial entre o visitante que chega e a própria cidade:

quem visita tal casa

não só passeia nela:

geralmente se casa

com ela, ou se amanceba..$^{18}$

O contraste externo-interno de Olinda pode ser enunciado como uma variante da dicotomia modernidade-tradição apontada na própria imagem da cidacle pernambucana, bem como na de Brasília. Por sua vez, esta dicotomia reflete uma outra presente na obra cabralina. Trata-se de uma poesia para o olhar, portanto, espacial, de acordo com o que foi discutido no início deste trabalho. Não obstante, a construção poética de João Cabral de Melo Neto é, de forma determinante, atrelada ao verso frásico tradicional. O caráter espacial desta poesia se efetiva, paradoxalmente, na linearidade da palavra. Esta compleição dicotômica confirma assim a proposição inicial de que conhecer as cidades cabralinas implica analisar os recursos estruturadores desta poética e, inversamente, a leitura da poesia pressupõe uma análise das imagens de cidade ali configuradas.

\section{Cidade, representação e epistemologia literárias}

Quando se pensa nas cidades que o texto literário configura, sempre volta a questão da representação. A discussão sobre a relação entre a literatura e o mundo se inicia com $A$ poética de Aristóteles e a sua noção de mímese. Sob uma leitura tradicional, este texto fundador parece propor que a finalidade da literatura seria a representação, em molde especular, da realidade. Ao longo da história ocidental, outras correntes teóricas, como o humanismo, o realismo naturalista do século XIX e o marxismo, também corroboraram essa forma de pensamento. As teorias críticas do início e meados do século passado (formalismo-estruturalismo), no entanto, rompem com esta visão e instituem o que se chamou de ilusão da referencialidade.

${ }^{18}$ MELO NETO, 1999. p. 431. 
O pensamento estruturalista é calcado na lingüística saussuriana, segundo a qual a linguagem é formada por um sistema de signos a ser analisado sincrônica e diacronicamente. Cada signo, por sua vez, se constitui de um significante e um significado, cuja relação não se pauta em nenhuma pressuposição inerente à natureza sígnica; é, ao contrário, arbitrária; bem como aleatório é o vínculo entre o signo e o seu referente. De modo similar, o texto literário, sob o enfoque estruturalista, é visto como um sistema sígnico e o interesse que desperta está mais voltado para a sua "estrutura profunda" que propriamente para o sentido que possa produzir. Assim, indivíduo-interpretante e objeto real são colocados entre parênteses na apreciação estruturalista.

Com efeito, um estudo estrutural da literatura propõe rigor analítico e o estabelecimento de leis universais, como se o indivíduo (o autor e/ ou o leitor) e a sociedade (contexto) fossem apenas construtos regidos por estruturas encovadas, intangiveis à consciência humana. Logo, tal qual o signo se aparta do seu referente na proposta teórica de Saussure, a literatura se abstrai de qualquer realidade exterior a si mesma e se configura como um sistema fechado e autônomo, cujos elementos constituintes podem apenas ser reformulados em interações recíprocas e nunca aludem ao mundo palpável. Toda tentativa de identificar outra função na literatura que não a de falar cle si própria pode ser taxada de ilusória, tornando desacreditada, assim, a possibilidade de representação literária especular.

Opondo-se a uma tentativa simplista cle imitação, as cidades cabralinas não desejam mostrar como de fato são as cidades no nosso espaço empírico; muito embora permitam sua abordagem, inclusive pelo viés crítico da denúncia social, não-panfletária, nem partidária (cumpre frisar bem). De fato, não é possivel o retorno às inocentes crenças de que a arte deve reproduzir a realidade. Confirma-se, então, a impotência da linguagem na tentativa de representação.

Mas João Cabral, como já salientaram diversos críticos, produz uma poesia para o olhar e elege como eixo de seu trabalho a concretude do que lhe é externo. $O$ "fora" é, em seu processo poético, um fator essencial que lhe garante o distanciamento da subjetividade intimista própria da lírica tradicional. Sua poesia se constrói no movimento que parte das impossibilidades das palavras em direção a um exterior que, se sabe desde o início, é intangível.

Não há nas imagens citadinas o intento de representação especular por parte da poesia, mas há uma interpretação que surge a partir de dados 
concretos da cidade. Como se vê, portanto, a poesia de Cabral não quer ter uma função mimética; contudo, ela nos remete ao contexto de sua produção e não se furta a uma perspectiva referencial. De uma referência que, no entanto, se produz a partir da verificação de impossibilidade de um projeto especularmente representacional.

Neste ponto, as conceituaçōes de Wolfgang Iser parecem responder melhor às interpelações que a poesia cabralina faz ao turista-leitor das cidades que ela expõe à visitação. Iser propõe a existência de um elemento intermediário entre a ficção propriamente e a realidade: 0 imaginário, veiculado por meio do que o pensador chamou de ato de fingir. A principal característica deste seria uma transgressão de limites, começando pela transgressão da realidade vivencial, ao transformá-la em signo no texto literário, e pela transgressão do imaginário, ao atribuir a ele uma determinação que contraria o seu caráter difuso. Desta maneira, o texto literário se constitui através da interação entre fictício-realidadeimaginário, e os atos de fingir são os mecanismos operatórios através dos quais estas relações se efetivam.

Ao ser elaborada, toda forma de expressão literária toma alguns elementos do mundo real; o termo alguns indica que há uma seleção. No ato de selecionar ocorre uma transgressão do sistema inicial para que os elementos dele retirados sejam recontextualizados; portanto, a seleção é um ato de fingir. A própria tentativa de contextualizar novamente o que foi retirado de sua situação original caracteriza-se como uma transgressão; por conseguinte, também a combinação, "que abrange tanto a combinabilidade do significado verbal, o mundo introduziclo no texto, quanto os esquemas responsáveis pela organização dos personagens e suas ações" ${ }^{10}$ é um modo operatório das relações entre a tríade que define o texto literário.

Outro ato de fingir explicitado por Wolfang Iser é o desnudamento da ficcionalidade, que consiste em sinais textuais indicadores do caráter ficcional do texto, assimilados através de convenções preestabelecidas, as quais são sujeitas a variações no tempo e compartilhadas entre leitores e autores. Ao mostrar a postura fingida do texto, o desnudamento da ficção mostra que a representação não é idêntica à realidade, mas que dela extrai fragmentos. Assim, o mundo moldado no texto se apresenta claramente

${ }^{19}$ ISER, 2002. p. 963. 
reconhecível, mas agora colocado entre parênteses para que se compreenda que não deve ser assimilado a partir dos mesmos pressupostos que regem o mundo real, pois se configura enquanto um como se: não se trata da realidade, mas é como se fosse.

A propósito, as cidades nordestinas que compōem a trajetória do Capibaribe desde sua nascente até a cidade do Recife seguindo o caminho de $O$ Rio delineiam-se como estratégias ficcionais que possibilitam a apreensão de toda uma realidade localizada e histórica. São vilas bem pequenas ou cidadezinhas, como Brejo da Madre de Deus, na margem direita, e Taquaritinga, na esquerda. De qualquer lado, sempre a mesma escassez: "coisas poucas/e secas além de sua pedra"..$^{20}$ Cada vila a que se chega tem um santo padroeiro: Couro d'Anta e Toritama, que antes se chamava Torres, são clevotas de Nossa Senhora da Conceição; de Santo Antônio são os fiéis de Poço Fundo, e em Santa Cruz "reina" o Senhor Bom Jesus; sem falar de Topada, cidade na qual um cemitério se estende, completando a igreja local. Após especificar o objeto de clevoção de cada localidade, a voz lírica acrescenta: "Sempre um santo preside / à decadência de cada uma delas". ${ }^{21}$ Este comentário é carregado de ironia e alude ao estreito vínculo social entre pobreza e religiosidade.

Se, para continuar conhecendo as cidades das margens do Capibaribe na poesia cabralina, formos a Toritama, passando por Santa Cruz, ${ }^{22}$ nos sentiremos coagidos a nos deter e mirar o arredor: há um convite insistente à eternização dos feitos da terra, tal como ocorre nas epopéias. "Mas é paisagem em que nada ocorreu em nenhum século". ${ }^{23}$ A ruína divisada é fingida, pois a ciclade não foi palco de imponentes lutas, cujas glórias devam ser narradas. Nem mesmo os conflitos que dão motivos aos cantos de feira (bem menos valorizados que os cantos épicos) são ali encontrados. Não existiram monumentos ou histórias que pudessem ser clestruídos. A devastação e a batalha constante constituem

${ }^{20}$ MELO NETO, 1999, p. 121.

${ }^{21}$ MELO NETO, 1999, p. 122.

${ }^{22}$ Aqui, a análise desloca-se do livro em questão, $O$ rio, e incorpora um poema de Paisagens com figuras, já que, nos dois casos, a mesma cidacle é tematizada. Logo em seguida, continua-se a falar das cidades presentes no longo poema de 1953.

${ }^{23}$ MELO NETO, 1999. p. 152. 
a própria fisionomia do ambiente. No entanto, por ser silenciosa, esta peleja "não é tema de canção":24
E luta contra o deserto, luta em que sangue não corre, em que o vencedor não mata mas aos vencidos absorve.
É uma luta contra a terra e sua boca sem saliva, seus intestinos de pedra, sua vocação de caliça,
que se dá de dia em dia que se dá de homem a homem, que se dá de seca em seca, que se dá de morte em morte. ${ }^{25}$

Não há vidas decapitadas em moldes dramáticos e violentos na guerra pela sobrevivência contra a seca, mas um morrer paulatino, expresso neste poema de Paisagem com figuras pela idéia de que os "vencidos", embora não sejam mortos pelo vencedor - o singular e o plural são significativos: representam a luta de toda uma população contra um único inimigo -, são por ele absorvidos. A anáfora do termo luta nas duas primeiras estrofes, bem como a que ocorre com a expressão "que se dá de" nos quatro últimos versos indicam a incisiva continuidade da mesma situação.

Em todo o poema, percebe-se uma contraposição entre ruína, enquanto destroços - "cena para cronicões,/para épicas castelhanas" ${ }^{26}$-, e a paisagem que é arruinada por constituição própria - por isso inadequada para qualquer tipo de representação artística ou literária. Este procedimento é uma forma de acusar o desprezo e esquecimento geral a que são relegadas as vítimas da aridez nordestina.

Varia a margem e mudam os nomes, Caruaru, Vertente, Surubim, João Alfredo, mas não muda o que se vê:

${ }^{24}$ MELO NETO, 1999. p. 153.

25 MELO NETO, 1999. p. 153.

${ }^{26}$ MELO NETO, 1999, p. 152. 
Entretanto a paisagem, com tantos nomes, é quase a mesma.

A mesma dor calada, o mesmo soluço seco, a mesma morte de coisa que não apodrece mas seca. ${ }^{27}$

Léguas à frente, é possível encontrar uma cidade um pouco melhor, muito embora também ali persista a mesma sede de seu arredor: Limoeiro, "cidade cortada a faca na ribanceira". ${ }^{28} \mathrm{O}$ seu avanço em relação às outras cidades adjacentes é percebido pela rua e igreja maiores, bem como pela presença da cadeia. Além disso, há duas feiras, que se realizam toda semana, e as "bolandeiras/ onde trabalha a gente/ para quem se fez aquela cadeia". 29 Esta consideração, realizada através da justaposição de duas categorias opostas pele senso comum (gente que trabalha, gente que vai para a cadeia.) é, de novo, pautada pela ironia crítica da voz poética a questionar uma concepção, e mesmo prática, de progresso que exclui a justiça social para, camuflando esta supressão, se restringir a efeitos paliativos, como a construção de prisões em cidades cujo tamanho e condições econômicas e sociais demandam outras instituições com função democrática mais definida.

A próxima cidade, Ribeiro Fundo, é de ferreiros, cujas mãos se fazem mais duras que a dureza vivenciada, para retirar da terra o "fruto secreto"30 e tenaz que lhes garante o sustento. De ferro têm de ser, igualmente, as mãos que roçam terras alheias, Boi-Seco, Feiticeiro, Gameleira, Ilhetas; a mesma dureza com a qual se depara no metal de Ribeiro Fundo é encontrada nesses arruados (que são sempre de outrem) e, por isso, com esta mesma característica as mãos são solicitadas. A imagem citadina, tal como a poesia de João Cabral de Melo Neto, mais uma vez, aponta a miséria e a opressảo. A insistência em frisar o "alheio" faz referência à alienação do sertanejo explorado, trabalhando no que não é seu para recolher o resultado que outros usufruirão:

\footnotetext{
27 MELO NETO, 1999, p. 123.

${ }^{28}$ MELO NETO, 1999,. p. 124.

${ }^{29}$ MELO NETO, 1999, p. 125.

30 MELO NETO, 1999. p. 125.
} 


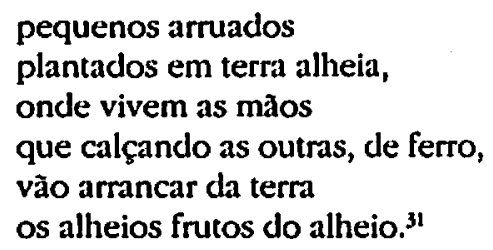

Mesmo quando, em seguida, as cidades em foco não são mais as de constituição árida, a poesia não deixa de apontar a permanência da mesma situação de miséria. "Na Mata, a febre, a fome/ até os ossos amolecem". O úmido e o seco, portanto, conforme nos indica a poesia, não se diferenciam substancialmente no Nordeste. Carpina é a cidade limítrofe ${ }^{32}$ nas subdivisões nordestinas. A sua principal característica está no clima ambíguo, pois é "agreste em parte/ e mata a outra metade ${ }^{33}$. A duplicidade aqui é ocasionada pelo trabalho seletivo da "chuva engenheira" que demarca a fronteira, como se edificasse uma cerca, ou como se construísse um "telheiro, invisivel, de vidro" ${ }^{\text {"34 }}$ sobre o Agreste. Estas imagens de trabalho e intencionalidade fluviais representam a divisão muito próxima entre o espaço árido e a terra produtiva.

Rosarinho, Desterro, Paudalho, São Lourenço, Santa Rita e outras vilas menores (pertencentes à parte produtiva do Nordeste) demonstram com nitidez o processo de transformação pelo qual passaram. Os grandes e poderosos engenhos cederam espaço às mais modernas e eficientes usinas. Os primeiros são caracterizados como "caldeiras vivas" e as usinas são consideradas "informes / partidos que nada identifica"35. Além disso, a metáfora para falar desta substituição é a do devoramento. A princípio, pode-se notar no "vivas" da adjetivação dos engenhos e no "informes" usado para falar das usinas uma tomada de partido em prol daqueles. No entanto, à frente, fica claro que há a consciência de que também os

31 MELO NETO, 1999. p. 125.

32 Neste ponto, aproveitou-se a menção à cidade de Carpina em $O$ Rio para analisar a imagem de cidacle veiculada por outro poema, "Chuvas", de Serial. 33 MELO NETO, 1999, p. 314.

34 MELO NETO, 1999, p. 315.

3s MELO NETO, 1999, p. 131. 
engenhos eram "devoradores": "as moendas dos engenhos / que mastigavam antes outra gente. ${ }^{36}$

De um modo geral, estas imagens citadinas na poesia cabralina veiculam uma irônica crítica ao contexto socioeconômico a que se reportam. Assim, tanto o Sertão, quanto as cidades da zona da mata e os mangues da capital, tematizados no livro $O$ Rio, são abordados sob a mesma perspectiva e apontam uma mesma situação: a da escassez. Não se percebe nenhuma tentativa de realizar uma literatura engajada, nem mesmo de descrever com precisão e fins definidos a realidade extratextual a que se referem. Ao contrário, as cidades são claramente explicitadas enquanto construto poético; o "como se" é desvelado pela poesia em todo o seu decurso. A este respeito, vale lembrar a estratégia discursiva deste livro. A voz enunciativa do poema é conduzida pelo rio, em primeira pessoa. A personificação do elemento natural se concretiza como uma espécie de contrato entre obra e leitor, justamente o que Iser denominou "desnudamento da ficcionalidade", o terceiro ato de fingir que permite a interação entre o fictício, a realidade e o imaginário (interação própria do texto literário).

No entanto, conforme se demonstrou, estas mesmas imagens que não se apresentam como representação das cidades, a elas são remetidas, já que não são criadas do vazio, mas partem de referências concretas e permitem que se apreendam as particularidades de cada espaço, bem como a historicidade do processo que as envolve. Não se deve, portanto, elaborar a questão em termos de oposição entre "ficção" e "realidade", mas sim, usando termos de Wolfgang Iser, estabelecer "relações, em vez de determinar posições". ${ }^{37}$

Colocada nestes termos, a representação se constitui sobre uma outra face: a possibilidade epistemológica cla literatura. Neste sentido, as cidades que permeiam o texto poético não são as mesmas do espaço empírico. A Recife e as outras cidades nordestinas, a Berna, a Quito, a Sevilha, etc., na poesia de João Cabral de Melo Neto, não são as cidades que podem ser identificadas na Geografia; elas surgem como "outras" que se definem a partir da sua constituição discursiva. Entretanto, elas apontam para fora da poesia e se estabelecem como resultado interpretativo, tomam

\footnotetext{
${ }^{36}$ MELO NETO, 1999, p. 131.

${ }^{37}$ ISER, 2002. p. 960.
} 
elementos presentes na realidade, os transgridem pela escolha pessoal do olhar do poeta para, novamente transgredindo, os impetrar no como se da literatura. Desta forma, as cidades na poesia se configuram como instrumento para o conhecimento humano do mundo; de forma específica, para o conhecimento da cidade. Certificam, então, a capacidade epistemológica da literatura e, de modo geral, legitimam o saber veiculado pela linguagem figurada ou metafórica.

Sob estas considerações, depois de se identificar a escassez como propriedade manifestada pela poesia nas cidades nordestinas que margeiam o rio Capibaribe, deve-se dirigir a uma outra cidade que possui uma caracterização - desértica - semanticamente próxima. Trata-se da Medinaceli cabralina, vulto da destruição, mas, ao mesmo tempo, da ferrenha resistência. Sua corporatura de "esqueleto já folgadon’38 foi moldada pelas guerras que sediou em virtude de sua localização estratégica; já a relutância mostrada se efetiva com o ecoar do Cantar de Mío Cid que se prolonga até a atualidade:

\author{
Medinaceli era o centro \\ (nesse elevado plantão) \\ do tabuleiro das guerras \\ entre Castela e o Islào, \\ entre Leào e Castela, \\ entre Castela e Aragão, \\ entre o barão e seu rei, \\ entre o rei e o infança, \\ onde os engenheiros, armados \\ com abençoados projetos, \\ lograram edificar \\ todo um deserto modelo. \\ (...) \\ pouca coisa the sobrou \\ se não foi o poemào \\ que poeta daqui contou \\ (talvez cantou, cantochão)
}

${ }^{38}$ MELO NETO, 1999. p. 148. 
que poeta daqui escreveu

com a dureza de mào

com que a gente daqui

diz em silêncio seu não."

A cidade é modelo por ser deserta; volta aqui a mesma idéia desenvolvida na "Fábula de Anfión". No poema de Psicologia da Composição, o deserto é buscado como espaço árido, por conseguinte, estéril, em que predominam o vazio e o silêncio, sendo este a única alternativa à incapacidade de se encontrar condições propícias à composição de uma poética oposta à lírica fácil e melódica, com modulações rítmicas não controladas pela razão. Nesse sentido, pode-se dizer que, em ambos os poemas, o deserto serve como paradigma.

No entanto, se, na "Fábula", o deserto apresenta como opção o silêncio estéril da flauta seca que seca - observe-se que o secar é simultaneamente atributo e ação do instrumento musical -, no deserto de Medinaceli, um canto é o único subsistente. Tal canto não poderia ser outro senão um cantochão: esta modalidade, oriunda dos ritos litúrgicos da igreja católica romana, pode ou não ser produzida por um ritmo; nas duas ocorrências, o procedimento se baseará apenas na acentuação e nas divisões do fraseado. O canto, no poema de Paisagens com figuras, é, portanto, uma antilira - empregando aqui o termo cunhado por Costa Lima - e, por isso, logra realizar o que a flauta de Anfión não pôde: ser seco e secar (é, de fato, um autêntico cante a palo seco, já que dispensa acompanhamento instrumental e melodia). A ingerência do cantochão na paisagem citadina - o secar - se concretiza na permanência da negatividade abrolhada em sua elaboração. Da mesma maneira em que o canto foi escrito "com a dureza de mão" (imagem avessa a uma idéia de facilidade, logo, remissiva à de negatividade), "a gente" da cidade persiste dizendo não, por meio de um dizer que é silencioso, semelhante ao canto sem musicalidade, mas incisivo. Paisagem e canto citadinos também a própria poesia cabralina - compartilham, portanto, os mesmos atributos, aos quais a metáfora do deserto corresponde bem: antilirismo e negatividade.

Mais uma cidade, agora da América espanhola, Quito, com seu "cone perfeito e de neve", 40 referência ao tracejo das fronteiras da cidade,

39 MELO NETO, 1999. p. 148-149.

to MELO NETO, 1999. p. 569. 
contribui também para o ensinamento da arte poética: ela "vem lembrarme que a boa eloqüência/ é a de falar forte mas sem febre". "O conceito de uma eloqüência que não se deixa contaminar pela febre relaciona-se com a lição aprendida pelos vulcões, a de "ser sem berrar". ${ }^{42}$ "Febre" e "berrar" aludem à erupção do material magmático à superfície terrestre e conferem aos elementos por estes termos referidos a noção de impetuosidade e ardência. Destas considerações, pode-se também inferir que a presença excludente da preposição sem antecedendo estes dois termos representa a inatividade dos vulcões. Por analogia, é possível estender as significações depreendidas da metáfora relativa à natureza vulcânica ao ato da composição poética. João Cabral de Melo Neto busca para suas obras justamente a lição instruída pela cidade, a de ser comedida, sem o uso de vocábulos retóricos ou adjetivações excessivas; ainda, sem a tentativa de expressão do sentimento interior tendente a se extravasar através de versos intimistas.

A partir destas imagens, verifica-se que as cidades cabralinas dialogam com o espaço empírico a que se referem e assim o fazem na proporção em que corroboram os mesmos ideais poéticos da obra na qual estão inseridas. Se, pois, é a escassez a característica identificada pelo eulírico na paisagem citadina, também o é o modo de dizê-la, por não se pautar em estratégias retóricas; quando se apresenta desértica a imagem de cidade, a poesia que a enuncia assenta-se sob a negatividade e 0 antilirismo; ainda, é moderada e simples a enunciação da imagem citadina que assim é configurada.

Esta mesma associação é estabelecida quando os elementos referenciais da poesia não são propriamente tangiveis. Consideram-se nãotangíveis os que dizem respeito à ordem da abstração em oposição à de concretude. Este é o caso das situações em que os versos poéticos captam das cidades, para a construção da imagem ficcional, qualificações que se relacionam com questōes de ambiência. A título de exemplo, pode-se citar a capital espanhola cabralina, cuja imagem se calca na oposição entre mobilidade / cristalização, e a configuração da imagem de Barcelona, Londres e Paris enquanto cidade-predicação.

11 MELO NETO, 1999. p. 569.

${ }^{42}$ MELO NETO, 1999. p. 569. 
À primeira vista, "cristalizada, /surge Madrid a quem chega" ${ }^{43}$ esta imagem é oposta à das cidades andaluzas - onde o flamenco é o símbolo do movimento e alegria contagiantes - por figurar imobilidade, fixidez. Em um poema de Agrestes, encontra-se uma justificativa: "Madrid? É o lugar onde vais/dançar, mas há carros demais". ${ }^{4} \mathrm{O}$ alarido dos grandes centros urbanos nâo rompe a "cristalizaçào" da cidade que representa justamente a dispersão e a falta de acolhimento que a vida moderna impõe. Todavia, palmilhando-a melhor, se percebe que a cidacle se abstrai, parcialmente, do predicado dominante em toda a região espanhola à qual pertence. Na estrofe abaixo, Castela é denominada "monja e bispa", alusão ao aspecto de seriedade que caracteriza as instituições religiosas. Ponderando esta circunspecção, o contorno de Madri se define pela concessão ocasional ao riso:

Dentro da vida de Madrid, oncle Castela, monja e bispa, alguma vez deixa-se rir, deixa-se ser Andaluziats

Somos compelidos a visitar Barcelona em simultâneo deslocamento em direção a Paris e Londres. As três cidades aparecem juntas na poesia de João Cabral de Melo Neto como adjetivações de um modo de viver. A estrofe do poema que as arquiteta, "Uma Sevilhana pela Espanha", é introduzida pelo advérbio durante, o qual, no seu uso convencional, diz respeito a um transcurso no tempo, mas, no poema, se refere a um espaço urbano, as ruas de Barcelona. A "des-substancialização" dos nomes das cidades é, portanto, antecipada pelo rompimento da aplicação ordinária deste termo. Paris é posta com letras minúsculas, como predicativo de ruas: "Durante essas ruas paris". De modo semelhante, Londres se transforma em um adjetivo da "gente" que transita pela cidade espanhola: "entre uma gente meio Londres/urbanizada em mansas filas" e a própria Barcelona é qualificada pela desapropriação da determinação morfológica do substantivo avenida: "Barcelona tão avenida". As predicaçôes assinaladas - ruas paris, gente meio londres e Barcelona tão avenida - se

\footnotetext{
${ }^{43}$ MELO NETO, 1999, p. 156.

"4 MELO NETO, 1999, p. 545.

45 MELO NETO, 1999, p. 322.
} 
direcionam, todas elas, para uma conjuntura, um estado, uma maneira de ser ou viver pautada na formalidade e decalque social. Neste poema, especificamente, tais atributos se opõem aos que são conferidos à sevilhana, representante da cidade de Sevilha.

Nos dois casos analisados, o de Madri e o das três cidades que aparecem juntas, há uma contraposição às caracterizações que são, nos últimos livros de João Cabral de Melo Neto, associadas à Andaluzia e sua cultura ou habitantes. Intimidade, aconchego, vivacidade (embora permanente e paradoxalmente sob o signo da contenção), em oposição às noções de cristalização e convencionalismo, são atribuídos a Sevilha; e, a partir destas qualificações, é formulada também uma postura poética de reconsideração do rigor restritivo da poesia cabralina ${ }^{46}$. Desta forma, as imagens de Madri, Barcelona, Paris e Londres são construídas em confronto com a da capital andaluza. Para tanto, os elementos empíricos tomados não dizem respeito aos aspectos físicos do espaço citadino, mas sim à movimentação anímica do ambiente urbano. Mesmo assim, validase a proposição inicial de que a cidade e a sua versão literária (a cidade elaborada pela consciência de que se constitui em um como se) e a poética de João Cabral de Melo Neto se configuram sob os mesmos parâmetros, se não pela relação direta, pelo menos através do estabelecimento dos predicativos em confronto.

A fixidez madrilenha e o artificialismo social de Barcelona, Londres e Paris aproximam-se da submissão suiça na relação conflitiva que mantêm com a concepção do fazer poético cabralino, conforme se pode inferir da imagem de Berna. Se embarcarmos nas assonâncias e aliterações desta poesia de uma única estrofe, encontraremos a voz "insubmissa" da cidade, que se opõe ao país como um todo:

Saudades de BerNa

Onde jamais reencontrar a submissa ambiência suiça?

Onde outra vez reencontrar A insuiça voz insubmissa?"7

${ }^{46}$ Este argumento será melhor desenvolvido em um outro artigo, cujo foco seja propriamente a cidade de Sevilha.

47 MELO NETO, 1999, p. 404. 
A imagem desta cidade se constrói a partir de uma estrutura incomum na poética cabralina, caracterizada por Marta Peixoto como "fundada na argumentação intelectual". ${ }^{48}$ Diferentemente das afirmações produzidas pelo raciocínio lógico da maioria dos versos do poeta, estes se armam através da formulação de indagações. Duas apenas, ambas se introduzem com o pronome interrogativo onde, também é única a resposta, que deve ser procurada no título. Assim, o caráter insubmisso da cidade se delineia pela contraposição de elementos com um matiz negativo em construçōes frásicas que pressupõem questões afirmativas.

$\mathrm{Na}$ primeira interrogação, há o advérbio de negação jamais associado, contraditoriamente, à propriedade submissa e ao verbo reencontrar, com esta disposição vocabular, se pode concluir que o eulírico identifica um feitio de submissão na Suiça, mas julga impossivel apontá-lo em Berna. O prefixo indicador de reincidência re-justifica o sentimento de saudade anunciado no título. Na segunda pergunta, a anteposição entre Suiça e Berna é empreendida pelo acréscimo de outro prefixo latino, in - relativo à negação -, ao nome do país, criando o neologismo insuiça. Desta maneira, dedução semelhante a anterior pode ser realizada; agora, contuclo, por via adversa: é justamente pelo que não caracteriza o país que se determinará a feição da cidade.

A idéia implícita na caracterização citadina como insubmissa também aponta para o fazer poético cabralino. Com efeito, o conceito de poesia elaborado em toda a obra de Joào Cabral de Melo Neto defende a atitude altiva de condução lúcida da composição. Isto implica a postura de não-submissão à escrita espontânea e intuitiva que foi pleiteada pela tradição romântica. Berna e poesia, assim, se respaldam pelo mesmo atributo: a independência discursiva. Reafirma-se, portanto, a relação estabelecida entre as imagens de cidade e a própria poesia cabralina.

4R PEIXOTO, 1983, p. 56. 


\section{Referências Bibliográficas}

ISER, Wolfgang. Os atos de fingir ou o que é fictício no texto ficcional. In: LIMA, Luiz Costa (Org.). Teoria da literatura em sulas fontes. 3. ed. Rio de Janeiro: Civilizaçăo Brasileira, 2002. v. 2, cap. 31, p. 955-984.

LE CORBUSIER. Urbanismo. 2. ed. Trad. Maria Ermantina Galvão Gomes..São Paulo: Martins Fontes, 2000. 307 p.

MELO NETO, Joāo Cabral de. Obra completa: volume único. Rio de janeiro: Nova Aguilar, 1999.

PEIXOTO, Marta. Poesia com coisas: uma leitura de João Cabral de Melo Neto. São Paulo: Perspectiva, 1983. 215 p.

SANTOS, Luis Alberto Brandảo. A cidade Arcaica. Aletria, Belo Horizonte, v. 6, 1999. p. 85-90.

SECCHIN, Antonio Carlos. João Cabral: a poesia clo menos. 2. ed. Rio de Janeiro: TopBooks, 1999. 333 p.

SOUZA, Helton Gonçalves. A poesia crítica de João Cabral de Melo Neto. São Paulo: Annablume, 1999. 220 p.

\section{Resumo}

A obra poética de Joào Cabral de Melo Neto é permeada por imagens de cidades. Analisá-las implica desenvolver discussões em torno do processo metalinguistico desta poesia e das questòes de representaçăo e epistemologia literárias. Estes pressupostos serào desenvolvidos neste texto, excluindo as imagens de Recife e Sevilha, as quais demandam um trabalho à parte.

\section{Abstract}

Joìo Cabral de Melo Neto's poetic work is permeated by city images. To analyse them implies the development of discussions around the metalinguistic process of this poetry and of literary epistemology and representation matters. These presuppositions are elaborated in this text, except Recife and Sevilla's images, which clemand an effort aside from this paper. 